\title{
Palladium Catalyzed Alternating Cooligomerization of Ethylene and Carbon Monoxide to Unsaturated Ketones
}

\begin{abstract}
Wilhelm Keim*. Heiko Maas. Stefan Mecking
Instilut für Technische Chemie der RW'TH Aachen. Worringer Weg 1. D-5207.A Aachen. Germany

Dedicated in Prof. Dr. Dr. H.c. muls. Giuther Wilke on the accasion of his $70^{\text {th }}$ hirthday

Z. Naturforsch. 50 b. 43(1)-43\$ (1995): received September 15. 1994

Cooligonacrization. Carlonylation. Pallaclium. Hemilabile. 13nsalurated Kełone

Cationic palladium calalysts have been used in cooligomerize ethviene and carhon nonoxide. Al high ethylene/CO ratios $(n / n)=1(1: 1)$ in methylene chloride as a solvent, unsaturated alternating cooligomers of the general structure $\mathrm{R}\left[\mathrm{C}(\mathrm{O}) \mathrm{CH}_{2} \mathrm{CH}_{2}\right]_{m} \mathrm{H}\left(\mathrm{m} \geq \mathrm{l}: \mathrm{R}=\mathrm{CH}_{2}=\mathrm{CH}\right.$. $\mathrm{CH}_{2}=\mathrm{CHC} \mathrm{I}_{2} \mathrm{CH}_{2}$ and $\mathrm{CH}_{3} \mathrm{CH}=\mathrm{CHCH}_{2}$ ) were ohtained for the first (inde. Single component catalyst precursors $\left[\left(\text { allyl) } \mathrm{Pd}\left(\mathrm{P}^{n} \mathrm{X}\right)\right]^{+} \mathrm{Y}\left(\mathrm{P}^{\wedge} \mathrm{X} \equiv \mathrm{Ph}_{2} P\left(\mathrm{CH}_{2}\right)_{n} \mathrm{C}(=\mathrm{O}) \mathrm{OR}\right.\right.$. $\mathrm{Ph} \mathrm{P}_{2} P\left(\mathrm{CH}_{2}\right)_{2} \mathrm{P}(=O) \mathrm{Ph}_{7}$, $\left.\mathrm{Ph}_{2} P\left(\mathrm{CH}_{2}\right)_{n} \mathrm{C}=\mathrm{CHCH}=\mathrm{CHS} . \mathrm{Ph}_{2} P\left(\mathrm{CH}_{2}\right)_{2} . \mathrm{S}(=) \mathrm{Ph} . n=1-3 . \mathrm{R}=\mathrm{Me} . \mathrm{El}: \mathrm{Y}^{-}=\mathrm{BF}_{4}{ }^{-} . \mathrm{ShF}_{\mathrm{g}}{ }^{-}\right)$ with bidentate P.O- and P.S-ligands as well as in situ calalysts wilh unfunctionalized phosphine ligands werc used. With ${ }^{n n} \mathrm{Bu}_{3}$ as a ligand, selectivitics for cthylvinylkctolte of $4(0) \%$ based on the CO converted were othiained. The hemilabile phosphino-ester and phosphinothiophene ligands behave like monodentate phosphines under catalytic eonditions.
\end{abstract}

\section{Introduction}

Unsaturatid ketones belong 10 a class of organic compounds of substantial synthetic interest. but their syntheses are often tedious. Potentially. an easy synthetic approach exists in the cooligomerization of olefins. especially ethylene. with carbon monoxide.

The first carbonylation reactions of olefins as pioneered by Roelen represent a milestone in the development of industrial. homogeneous transition metal based catalysis. Today. the oxo-synthesis represents the largest scale application of homogeneous catalysis.

In hydroformylation. as well as in other important carbonylation reactions of olefins. e.g. hydrocarboxylation and hydrocarbalkoxylation. the product contains one molecule of olefin and $\mathrm{CO}$. respectively. Products containing more than one molecule of olefin can also be obtained. Roclen already observed the formation of diethylketone as a byproduct in the hydroformylation of cuhylene [1]. and many other examples are known [2]. Diethylketune can also he obtained selectivcly [3].

Multiple incorporation of carbon monoxide can also occur, yielding saturated oligokctones

\footnotetext{
* Reprint requesis to Prof. Dr. W. Keim.
}

$\mathrm{H}\left[\mathrm{CH}_{2} \mathrm{CH}_{2} \mathrm{C}(\mathrm{O})\right]_{m} \mathrm{El}$ or oligoketocarboxylic acids or estcrs $\mathrm{H}\left[\mathrm{CH}_{2} \mathrm{CH}_{2} \mathrm{C}(\mathrm{O})\right]_{m} \mathrm{OR}(m>\mathrm{i}: \mathrm{R} \equiv \mathrm{H}$. alkyl). In addition to ethylene and carhon monoxide, the oligoketones contain two hydrogen atoms. usually originating from $\mathrm{H}_{2}$ added or derived from water via the water-gas shift reaction. The oligoketocarboxylic acids or esters contain one molecule of water or alcohol. added or used as a solvent. In an early publication. Reppe and Magin have described the nickel catalyzed synthesis of such oligomcrs along with high-molecular-weight polymeric products [4]. With rhodium catalysts. oligoketones and oligoketoesters $(m=1$ to approximatcly 4) can be obtained selectively under mild conditions [5]. Oligoketoesters can also be obtained with palladium catalysts $[6,7 \mathrm{~h}]$.

The formation of unsaturated ketones, consisting only of olefin and carbon monoxide. has also been observed. Propenylpropylketones can be derived from propylene and carbon monoxide with rhodium $[5 \mathrm{~b}]$ and palladium catalysts $|\delta|$. Employing styrene. 1.5-diphenylpent-1-en-3-one can be ohtained selectively [8.9]. Considering the synahesis of unsaturated ketones from ethylene and $\mathrm{CO}$. the transition metal catalyzed preparation of ethylvinylketene has becn described under severe conditions with moderate selectivities. using ruthenium, copper or silver catalysts [10]. Drent has brictly noted, that ethylvinylketone can be ob-

0932-0776/95/0300-0430\$(16.()) (c) 1)95 Vertag der Zeisschrill lür Nillurfurschung. All rights reserved. 
tained at low rates with $\mathrm{Pd}(\mathrm{OAc})_{2} / \mathrm{PPh}_{3} /$ phenylphosphonic acid as a catalysı [11].

Recently, the copolymerization of olefins and $\mathrm{CO}$. yielding alternating polyketones, has attracted much industrial [7] and academic [12] interest. Very active cationic palladium calalysts with chelating P.P- or N.N-ligands have been developed, and mechanistic considerations have contributed to the understanding of factors controlling claan growth and termination steps in this type of multiple carbonylation reactions.

For many years, we have been interested in transition metal catalysts with anionic chclating ligands. Exceptional results are oblained with bidentate P.O-ligands, which combine a hard and a soft donor atom. Such ligands are also applied commercially for the nickel catalyzed oligomerization of ethylene in the Shell higher olefin process [13]. Presently, we are also investigating nickel and palladium catalysts with comparable neutral ligands for $\mathrm{C}-\mathrm{C}$ linkage reactions of olelins $[14,15]$. Well characterized cationic palladium allyl complexes with bidentate P.O- and P.S-ligands are used as catalyst precursors. Thiese complexes are also well suited for mechanistic sludies, especially with view of applying hemilabile bidentate functionalized phosphine ligands in homogeneous catalysis. In this paper, we wish to report the cooligomerization of ethylene and $\mathrm{CO}$. yielding unsaturated low-molecular-weight alternating oligoketones. To the best of our knowledge, selective lormation of these compounds from ethylene and CO has not been reported before. The preparation and stoichiometric reactions of the cationic complexes applied $[16,17]$ will be subject of a separate publication.

\section{Results and Discussion}

In homogeneous catalysis by transition metal complexes. two approaches exist: the use of isolated. well characterized complexes as single-component catalyst precursors. and the use of in situ catalysts. In this study, both methods were employed.

Cationic palladium allyl complexes with P.Oor P.S-ligands as catalyst precursors'

Under identical pressures ol ethylene and carbon monoxide and in methylene chloride as a sol-
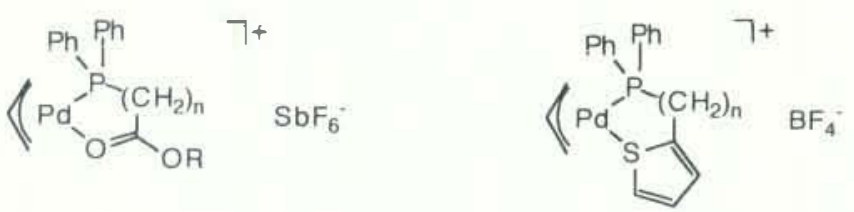

$1: n=1, R=M e$
$2 n=2, R=E t$
$3 n=3, R=E t$

4: $n=1$

5: $n=2$

6. $n=3$
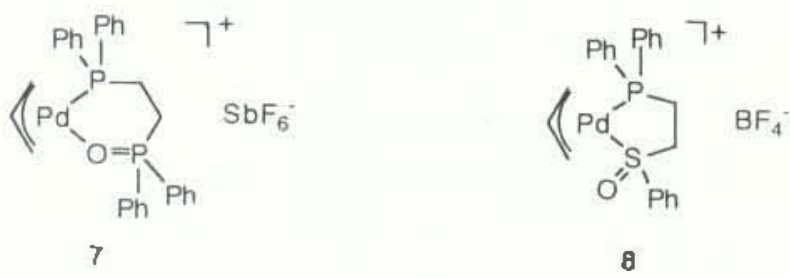

Fig. I. Cationic palladium allyl complexes used as cata. lyst precursors.

vent, the complexes shown in Fig. 1 catalyze the copolymerization of ethylene and $\mathrm{CO}$ to alternating polyketone. Molecular weights of the products are approximately $\nabla_{n}=2000-4000 \mathrm{~g} / \mathrm{mol}$. Compared to cationic palladium catalysts with bidentate P.P-ligands in aprotic [18] or protic solvents [7.18]. activities are moderate.

However, at high ethylene/CO ratios, oligomeric products with the structure shown in Scheme $?$ are obtained $^{+}$. Compounds with $m=1,2$ and 3 were separated and characterized by NMR. IR and mass spectroscopy. This data corresponds to literalure-known spectroscopic data [19]. Products with $m>3$ were not seperated, but NMR-spectroscopy shows, that these higher oligomers and polymers also have the general structure shown in Scheme 1.

These products can be interesting intermediates lor preparative organic chemistry, for which so far no simple high-yield syntheses are known. For ethylvinylketone even large-scalc applications can be envisaged, e.g. for copolymers. 1.4-Diketones can be used for the synthesis of substituted cyclopentenones, which are a structural element of natural fragrances of the jasmin-type [20].

\footnotetext{
+ In experiments carried out at high reaction temperatures $\left(\geq 110^{\circ} \mathrm{C}\right)$. in addition to the products shown in Schems I. a further isomer of the butenylketones was observed. For $m=1$ and 2 , this was identified as $t$ rams. 4-hcpten-3-one and trants-7-decen-3.ti-dione. respectively.
} 


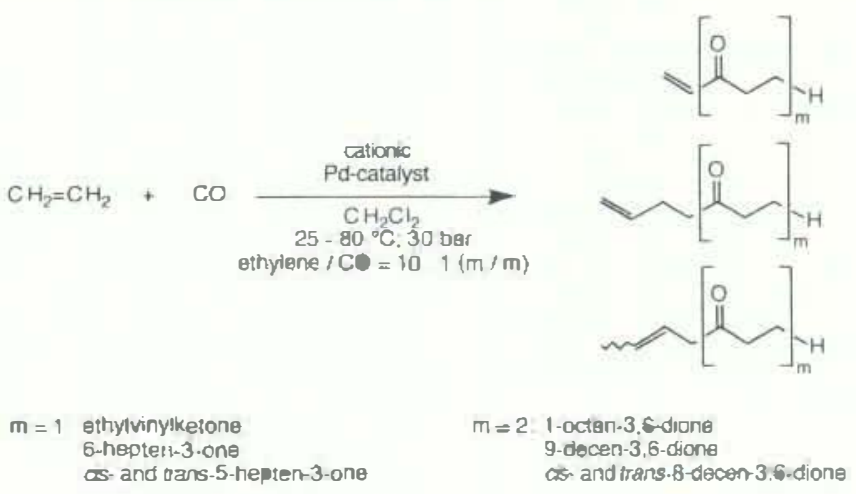

Scheme 1. Cooligomerization of ethylene and $\mathrm{CO}$
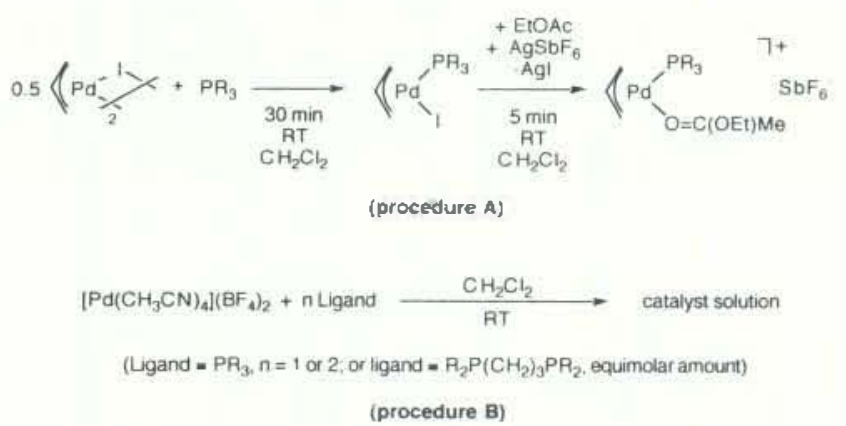

Scheme 2. Preparation of in siuu calalysts.

In standard work-up of the rection mixtures obtained from catalysis. the products with $m \geq 3$ were divided into the fraction dissolved in the given amount of solvent $(20 \mathrm{ml}$ methylene chloride) and into the undissolved fraction. consisting of polyketones. Comparison of the amounts of these iwo fractions can serve as a qualitative measure of the molecular weight of the products with $m \geq 3$.

L'sing complexes 1-6 (lable I) mainly low-molecular-weight products $(m=1,2$ and soluble oligoketones with $m \geq 3$ ) are obtained. whereas with 7 and 8 mainly insoluble polymers are obtained even at high ethylene/CO ratios.

The dependence on the temperature applied. shown tor complex 3 in Table 1I, is typical for complexes 1-6. At temperatures of $50-65^{\circ} \mathrm{C}$. the optimum of activity and catalyst stability is observed. at higher temperatures rapid catalyst decomposition occurs. Complexes 7 and 8 require higher temperatures. $80^{\circ} \mathrm{C}$ being the optimum. With all complexes. higher reaction temperatures favor the formation of low-molecular-weight products. As can be expected, chain-termination prevails over propagation (cf. Scheme 3).

Lowering the ethylene/CO ratio from 10:1 to 2:1 has the opposite effect (Table I1): at low COconcentrations. chain termination from an alkylspecies can compete with $\mathrm{CO}$ insertion. i.e. propagation. whereas at high $\mathrm{CO}$ partial pressures propagation prevails.

Figure 2 shows the course of reaction with compiex 3. Because of the difficulty 10 draw a representative sample of the heterogeneous reaction mixture from an autoclave under the reaction conditions, data points for each reaction time were determined by a separate experiment. Deviations are inevitable, and this is considered the reason for a slight lowering of the TON for $m=1$ and 2 after $14 \mathrm{~h}$ reaction time compared to $7 \mathrm{~h}$.

Table I. Cooligomerization of ethylene and CO employing complexes $\mathbf{1}-\mathbf{8}$ as catalyst precursors.

\begin{tabular}{|c|c|c|c|c|c|c|c|c|c|c|c|}
\hline \multirow{2}{*}{$\begin{array}{l}\text { Catalyst } \\
\text { Cat. }\end{array}$} & \multirow[b]{2}{*}{${ }_{[\pi ו m o l]}^{n}$} & \multicolumn{4}{|c|}{ Reacison conditions } & \multicolumn{6}{|l|}{ Resulis } \\
\hline & & $\begin{array}{l}\text { Temp. } \\
{\left[{ }^{\circ} \mathrm{C}\right]}\end{array}$ & $\begin{array}{l}\operatorname{Timc} \\
{[\mathrm{h}]}\end{array}$ & $\begin{array}{l}\text { Mass }\lfloor\mathrm{g}\rfloor \\
\mathrm{C}_{2} \mathrm{H}_{3}\end{array}$ & $\mathrm{CO}$ & $\begin{array}{l}\text { Conv. } \\
\text { of } \mathrm{CO}\end{array}$ & $\begin{array}{l}\text { TON } \\
\text { insol. }\end{array}$ & $\begin{array}{l}\text { (subsira } \\
\text { sol. } \\
m \geq 3\end{array}$ & $\begin{array}{l}m=1.2 \\
m=1(P J)\end{array}$ & total & $\begin{array}{l}\text { Sel. } \\
\text { Ev }|\mathrm{K}| \mathrm{a} \mid\end{array}$ \\
\hline 1 & 0.100 & 50 & 7 & 5.36 & 0.49 & $89 \%$ & 44 & 140 & 235 & 419 & $3 \%$ \\
\hline 2 & $0.100)$ & 50 & 15 & 5.06 & 0.52 & $95 \%$ & 159 & 120 & 1.34 & 413 & $2 \%$ \\
\hline 3 & 0.100 & 50 & 14 & 5.50 & (1. 52 & $96 \%$ & 66 & 171 & 207 & 444 & $10 \%$ \\
\hline 4 & $0 .(196$ & 50 & 15 & .7 .97 & 0.54 & 8()$\%$ & 67 & 167 & 1.54 & 388 & $5 \%$ \\
\hline 5 & 0.100 & 50 & 15 & +.102 & 0.50 & $47 \%$ & 164 & 110 & 1.34 & $4(1) 8$ & $3 \%$ \\
\hline 6 & 0.045 & 50 & 15 & 4.45 & 0.60 & $88 \%$ & 135 & 224 & 55 & 414 & $2 \%$ \\
\hline 7 & 0.100 & 80 & 20 & 5.51 & 0.53 & $98 \%$ & 209 & 60 & 22 & 381 & $11 \%$ \\
\hline 8 & (1).100 & 80 & 15 & 4.58 & 0.43 & $87 \%$ & 172 & 84 & 16 & 272 & $0 \%$ \\
\hline
\end{tabular}

Solvent: 20) $\mathrm{ml} \mathrm{CH}_{2} \mathrm{Cl}_{2}$; initial $\rho($ ethylene $)=25$ bar: initial $\mathrm{P}(\mathrm{CO})=5$ bar. a) selectivity for ethylvinylketone. based on the CO converled. 
T:tble II. Cooligomerization of elhylene and CO: influence of reiktion conditions.

\begin{tabular}{|c|c|c|c|c|c|c|c|c|c|c|c|}
\hline \multirow{2}{*}{$\begin{array}{l}\text { Cillallyst } \\
\text { Cill. }\end{array}$} & \multirow[b]{2}{*}{$\stackrel{n}{n}|\mathrm{~m} m(s)|$} & \multicolumn{4}{|c|}{ Reaction conditions } & \multicolumn{6}{|l|}{ Resulis } \\
\hline & & $\begin{array}{l}\text { Гemp. } \\
{\left[{ }^{\circ} \mathrm{C}\right]}\end{array}$ & $\begin{array}{l}\text { Mitss }|\mathrm{g}| \\
\mathrm{C}_{2} \mathrm{H}_{4}\end{array}$ & $\mathrm{CO}$ & $\begin{array}{l}\text { Ration } \\
\mathrm{C}_{2} \mathrm{~J}_{4} / \\
\mathrm{CO}\end{array}$ & $\begin{array}{l}\text { Cunv. } \\
\text { of } C()\end{array}$ & $\begin{array}{l}\text { TON/ } \\
\text { insol. }\end{array}$ & $\begin{array}{l}\text { (suhsiri } \\
\text { sol. } \\
m \geq 3\end{array}$ & $\begin{array}{l}\text { (mold }(\mathrm{d}) \\
m=1.2\end{array}$ & total & $\begin{array}{l}\text { Scl. } \\
\text { EVk|il| }\end{array}$ \\
\hline 3 & 0.102 & r.1. & 6.3 & (). .5 & 12 & $60 \%$ & 86 & 84 & fis' & 238 & $5 \%$ \\
\hline 3 & $(0.1(x)$ & 5() & 5.50 & 0.52 & i() & $4 反 \%$ & 66 & 171 & 207 & 444 & $10 \%$ \\
\hline 3 & (1).(1) & 65 & 4.7 & (1).5 & y & ()) $\%$ & 36 & 203 & 250 & 498 & $8 \%$ \\
\hline 3 & (1). (1999 & 95 & 4.5 & 0.5 & c) & $61 \%$ & 3 & 106 & 191 & $3(x)$ & $13 \%$ \\
\hline 3 & (0.103 & 140 & 5.2 & 0.5 & [1) & $35 \%$ & 2 & 54 & 115 & 171 & $18 \%$ \\
\hline 2 & $0.1(x)$ & 5() & 5.06 & $(0.52$ & I0) & $95 \%$ & 154 & 120 & 134 & 413 & $2 \%$ \\
\hline 2 & $0.1(x)$ & 5() & 5.19 & 1.04 & 5 & $71 \%$ & 491 & 33 & 3 & 527 & $0 \%$ \\
\hline 2 & $(0.10 !$ & 50 & $f_{1} .0$ & $3 .(\})$ & 2 & $1.3 \%$ & 2.56 & 12 & (i) & 268 & $0 \%$ \\
\hline
\end{tabular}

Solvent: $20 \mathrm{ml} C \mathrm{H}_{2} \mathrm{C} \mathrm{I}_{2}$ initial $\mathrm{p}(\mathrm{e}$ hylene $)=25$ bar: imitial $\left.\rho(\mathrm{CO})=5-36\right)$ bar: rcaction lime $15 \mathrm{~h}$. a) 5 electivity or elhylvinulketone. based on line CO converted.

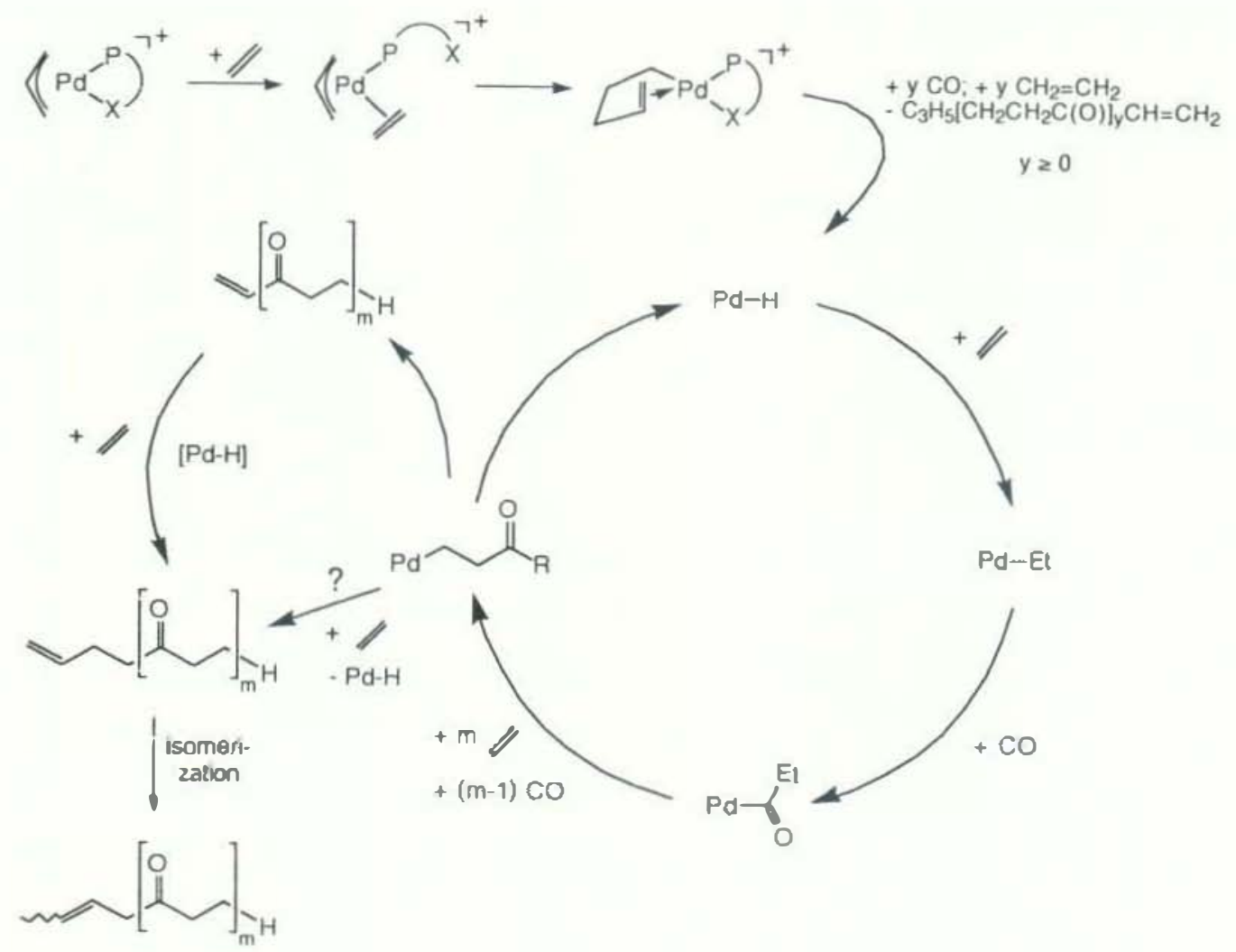

Schome 3. Proposed mechanism for the coolignmerizillim of athylene with CD. employing allyl complexes with hemilabife tunctionalized phosphime ligands as catalyst precursors.

The highest average reaction rate. TOF $=226$ $\mathrm{mol} / \mathrm{mol} \cdot \mathrm{h}$. is observed in the one hour experiment. The decrease in rate with time is probably due to partial catalyst decomposition. Nevertheless. complete conversion of CO can be achieved after 14 h reaction lime.
Due to the lact that the experiments shown in Fig. 2 were run in batchmode. the ethylene/CO ratio rises during the experiment because of the consumption of $\mathrm{CO}$ (simultancous consumption of ethylenc does not result in a significant change of the amount of ethylene. as it is present in a large 


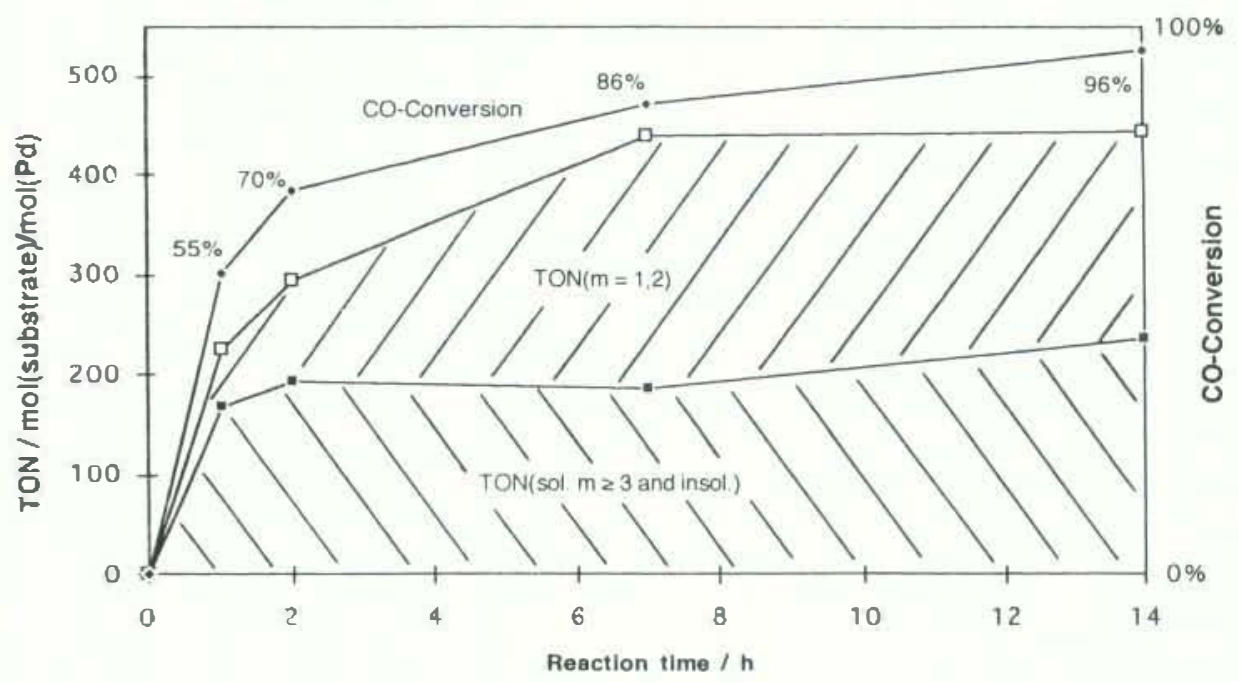

Fig. 2. Siclectivity and conversion ris. reaction lime (1).1 mmol complex 3 in $20 \mathrm{ml}$ $\mathrm{CH}_{2} \mathrm{Cl}_{2}$ : initial $\mathrm{p}(\mathrm{cthylene})=$ 25 bas and initial $\mathrm{p}(\mathrm{CO})=5$ bar: $50^{\circ} \mathrm{C}$ ). excess). As low CO concentrations favor the formation of low-molecular-weight products, only products with $m=1$ or 2 are formed after half of the $\mathrm{CO}$ has been consumed. Also, within this product fraction products with $m=1$ are then formed preferentially: after one hour the ratio ethylvinylketone/5- and 6-hepten-3-ones/l-octen3.6-dione/8- and 9-decen-3,6-diones is 80:100:78: 41, after complete conversion a ratio of $42: 100$ : 11:9 was obtained.

Considering the cooligomers with butenyl endgroups, depending on the reaction conditions and the catalyst precursor employed. either the terminal (i.e. 6-hepten-3-one for $m=1$ ) or the internal (i.e. trans- and cis-5-hepten-3-one for $m=$ i) isomers can predominate. Generally, under conditions which favor formation of low-molecularweight products. the internal isomers are obtained preferentially.

Using complex 7 (at $80^{\circ} \mathrm{C}$ ). activities are slightly lower than those observed for 3 ( $29 \%$ CO conversion after $2 \mathrm{~h} ; 46 \%$ after $4 \mathrm{~h}$ : complete conversion after $20 \mathrm{~h}$ ), but insoluble polymeric material is ohtained almost exclusively.

Allyl complexes with phosphino-thioether ligands $\mathrm{Ph}_{2} \mathrm{P}\left(\mathrm{CH}_{2}\right)_{n} \mathrm{SR}(n=2, \mathrm{R} \equiv \mathrm{Me}, \mathrm{Ph} ; n=3$, $\mathrm{R} \equiv \mathrm{Ph})$ and $o-\mathrm{Ph}{ }_{2} \mathrm{P}\left(\mathrm{C}_{6} \mathrm{H}_{4}\right) \mathrm{SR}\left(\mathrm{R} \equiv \mathrm{Me},{ }^{\mathrm{P}} \mathrm{Pr}, \mathrm{Ph}\right) \mathrm{ex}-$ hibit only low activities in the reaction of ethylene and $\mathrm{CO}$. Activation of these complexes is slow. E.g., in an experiment with $\left[\left(\mathrm{C}_{3} \mathrm{H}_{3}\right) \mathrm{Pd}\left\{o-\mathrm{Ph}_{2} \mathrm{P}\left(\mathrm{C}_{6} \mathrm{H}_{4}\right)\right.\right.$ $\mathrm{SPh}]-P . S] \mathrm{BF}_{4}$. stopped after 14 hours, $6(3 \%$ of the precursor complex were recovered unchanged.
Considering the coordination behaviour of the functionalized phosphine ligands applied during catalysis. it is conspicuous. that comparable results are obtained with the phosphino-ester complexes $\mathbf{1 - 3}$ as well as with the phosphino-thiophene complexes 4-6. Neither the chain length $n$ of the ligand backbone, nor the nature of the donor atom (- vs. S) have a strong impact on activity and selectivity. Also, with comparable in situ catalysts with unfunctionalized monodentate phosphines similar results are obtained (vide infra). This leads to the conclusion, that the P.O- and P,S-ligands in 1-6 behave like monodentate phosphines under catalytic conditions. These ligands are hemilabile in the sense. that the weaker donor atom (O.S) stabilizes the precursor complex and creates a free coordination site during the catalytic reaction. The markedly different selectivity with 7 and 8 can be attributed to bidentate coordination of the phosphino-phosphinoxide and the phosphino-sulfoxide ligand during catalysis. This interpretation is in accordance with stoichiometric experiments, using the catalyst precursors as model compounds [16.17]: the O-donor in $\mathbf{1 - 3}$ and the S-donor in 4-6 is quantitatively substituted by ethylene or $\mathrm{CO}$ upon bubbling the gas through a solution of the complex at room temperature and normal pressure. By contrast. with $\mathbf{7}$ and $\mathbf{8}$ the unchanged complexes prevail.

The allyt complexes 1, 2, 3 and 7 were also used as catalyst precursors in the absence of carbon monoxide. At $50{ }^{\circ} \mathrm{C}$ under a constant pressure of 
30 har. ethylenc is rapidly oligomerized with rates of up to $2000 \mathrm{~mol} / \mathrm{mol} \cdot \mathrm{h}$. With $1-3$ hutcnes are obtained with $>95 \%$ selectivity. By contrast. complex 7 yields significant amounts of hexenes (sel. $13 \% .60 \%$ linear) and octenes (sel. $1 \%$ ).

Cationic palladium catalysts modified by monoor bidentate phosphines are known to catalyze selective dimerization of ethylene [11,21.22]. whereas with bidentate N.N-ligands hexenes and higher oligomers were also sbtained [11.22\}.

Addition of ethylvinylketone or 1-octen-3.6-dione to an ethylent oligomerization reaction. catalyzed by complex 2 . resulted in formation of 5 - and 6-hepten-3-ones and 8 - and y-decen-3.6-diones. respectively, i.e. codimers of vinylketones and ethylene. The rate of homodimerization of ethylene. present in a large excess, was not significantly influenced. This observation suggests, that the butenylketones formed in cooligomerization of ethylene and $\mathrm{CO}$ are formed by codimerization of primarily formed vinylketones with ethylene. and not necessarily by subsequent insertion of two molecules of ethylene into a palladiumacyl hond.

\section{Experiments with in situ calalysts}

For rapid screening of ligands with different substituents attached to the P-donor and for comparison with complexes $\mathbf{1}-\boldsymbol{8}$, in silu catalysts with unfunctionalized phosphine ligands were used. Catalysts were prepared by the two routes shown in Scheme 2. Table III shows the results obtained with both catalyst systems, employing different ligands.

With allyl complexes prepared by route A. employing $\mathrm{PPh}_{2} \mathrm{Et}$ as a ligand. results comparable to those using the isolated complex 3 were obtained. Stopping the experiment after 2 hours and 6 hours. respectively, activities and selectivities very similar to those observed for 3 (Fig. 2) were found. With $\mathrm{P}^{\prime \prime} \mathrm{Bu}_{3}$ as a ligand, a slightly lower activity is observed in comparison to catalysts with aryl-substituted ligands. Remarkably. the share of oligoketones with $m=1$ and 2 is relatively high. and contains predominantly vinylketones. A selectivity for the desired athylvinylketone of about $40 \%$ based on the $\mathrm{CO}$ converted was ohtained. Catalysts with the hulky secondary alkyl phosphine $\mathrm{PC}_{3}$ were almost inactive.
The use of catalysts prepared by route $B$ for rcacting eihylenc and $\mathrm{CO}$ under identical pressures of both gases has already been described by Sen and others [6.18.21]. In aprotic solvents, high-molecular-weight alternating polyketones werc obtaincd. $\beta$-Hydrogen abstraction. resulting in formation of vinyl end-groupsi. has been proposed as a termination step [18].

Emploving catalysts prepared by route $\mathrm{B}$ at high ethylens/CO ratios (Table 111), cooligomers can be obtained. These products are the same as those obtaincd with allyl complexes as catalyst precursors, i.c. unsaturated ketones of the general structure shown in Scheme l are formed exclusively.

With $\mathbf{P}^{\prime \prime} \mathrm{Bu}_{3}$ as a ligand, again selectivities for ethylvinylketone of up to $40 \%$ are obtained. It was anticipated, that addition of more than one equivalent of phosphine ligand would stabilize the catalyst and also favor chain-termination by temporary blocking of coordination sites for propagation. Indeed, catalyst stability is improved, but selectivity is changed in favor of higher-molecular-weight products. With catalyst system B with one equivalent of $\mathrm{P}^{\prime \prime} \mathrm{Bu}_{3}$, increasing the reaction temperature from $50{ }^{\circ} \mathrm{C}$ to $80{ }^{\circ} \mathrm{C}$ resulted in an increase of the selectivity for ethylvinylketone. With all other catalysts with monodentate ligands given in Table III, increasing the reaction temperature did not result in a significant improvement.

As expected, applying the bidentate P.P-ligand 1,3-bis(diphenylphosphino)propane (dppp). copolymer is formed exclusively even at high ethylene/CO ratios. With the alkyl-substituted diphosphine 1.3-bis(di-is()-propylphosphino)propane (dippp) cooligomers can be obtained, but rates and selectivities are only moderate.

Generalizing, results obtained with in silu catalysts prepared by route B and with allyl complexes. prepared in sim by route $\mathrm{A}$ or used as isolated complexes, are comparable. One is tempted to speculate that similiar catalytically active species are formed during catalysis.

\section{Mec/umistic: considerations}

For the transition-metal catalyzed alternating cooligomerization and copolymerization of ethylene and $\mathrm{CO}$ in aprotic solvents, a hydride mechanism has been proposed by various authors [71, 11,12]. The initial palladium-hydride is 
Table III. Cooligomerization of ethylene and $\mathrm{C}($ ) by in siru catalysts.

\begin{tabular}{|c|c|c|c|c|c|c|c|c|c|c|c|}
\hline \multicolumn{3}{|c|}{ Cartalyst |a| } & \multicolumn{3}{|c|}{ Reaction conditions } & \multicolumn{6}{|c|}{ Results } \\
\hline Type & Ligand & "minol| & Temp. & \multicolumn{2}{|c|}{$\underset{\mathrm{C}_{2} \mathrm{H}_{1}}{\text { Miss }[\mathrm{g}]} \mathrm{CO}$} & $\begin{array}{l}\text { Conv. } \\
\text { of } \mathrm{CO}\end{array}$ & \multicolumn{4}{|c|}{$\begin{array}{l}\text { TON/mol(substrate)/mul(['d) } \\
\text { insol. sol. } \\
\quad m \geq 3 \quad m=1,2^{\text {total }}\end{array}$} & $\begin{array}{l}\text { Sel. } \\
\text { EVK|b| }\end{array}$ \\
\hline A & $\mathrm{PPh}_{2} \mathrm{E}_{1}$ & (0.089 & 50 & 5.26 & 0.56 & $91 \%$ & 39 & $2+12$ & 198 & .479 & $4 \%$ \\
\hline A & $\mathrm{P}^{r r} \mathrm{~B}_{3}$ & 0.114 & 50 & 5.1 & 0.5 & $74 \%$ & 11 & 78 & 207 & 296 & $43 \%$ \\
\hline A & $P C v_{3}$ & 0.1195 & 50 & 4.4 & 0.5 & $15 \%$ & 23 & 32 & 1 & 56 & ()$\%$ \\
\hline B & J'Ph_El I CU & (0.108 & $5(3)$ & 4.4 & 0.5 & $87 \%$ & 221 & 65 & 4 & 24() & $0 \%$ \\
\hline B & $\mathrm{PPh}_{3} \mid \mathrm{eq}$ & (0.096 & 50 & 5.25 & 0.58 & $83 \%$ & 183 & 48 & 238 & 469 & $6 \%$ \\
\hline B & $\mathrm{P}(\mathrm{OPh})_{3} \mathrm{leq}$ & $(0.00 \%)$ & 50 & 5.2 & 0.5 & $4 \%$ & 17 & () & () & 17 & $1) \%$ \\
\hline B & $\mathrm{P}^{\prime \prime} \mathrm{Bu}_{3} 1 \mathrm{cq}$ & 0.050 & 5() & 4.5 & 0.5 & $22 \%$ & 1 & 62 & 54 & 117 & $26 \%$ \\
\hline B & $\mathrm{P}^{n} \mathrm{Bu}_{3} \perp \mathrm{eq}$ & $0.09 ?$ & 80 & 4.5 & (0.6 & $20 \%$ & 1 & 34 & 88 & 123 & $4.1 \%$ \\
\hline B & $\mathrm{P}^{\prime \prime}\left[\mathrm{Bu}_{3} 2 \mathrm{C}\right.$ & (1).11? & 5() & 5.35 & (0.55 & $69 \%$ & (1) & $|6|$ & 114 & 275 & $15 \%$ \\
\hline B & $\mathrm{P}^{\prime} \mathrm{Pr}_{3} 2 \mathrm{eq}$ & 0.11 it & 50 & 4.26 & 0.39 & $1.4 \%$ & 0 & 20 & 17 & 43 & $9 \%$ \\
\hline 8 & $\mathrm{PCy}_{3} \geq \mathrm{eq}$ & 0.104 & 5() & 4.95 & 0.53 & $13 \%$ & 0 & 42 & 13 & 55 & $6 \%$ \\
\hline [c] & dppp I eq & $(0.13()$ & 7() & 9.4 & (0.2 & $4 \%$ & 103 & () & () & 103 & ()\% \\
\hline B & dippp 1 eq & (0.100) & 50 & 4.89 & 0.58 & $18 \%$ & () & 62 & 24 & 86 & $8 \%$ \\
\hline B & dippp 1 eq & (0.100) & 75 & 4.54 & 0.70 & $23 \%$ & () & 82 & 55 & 137 & $8 \%$ \\
\hline
\end{tabular}

Solvent: $20 \mathrm{mll} \mathrm{CH}_{2} \mathrm{Cl}_{2}$ : reaction lime $15 \mathrm{~h}$; initial $\mathrm{p}$ (ethylene) = 25 bar: instial $\mathrm{p}(\mathrm{CO})=5$ bar (experiment with dppp: $\mathrm{p}($ ethylene $)=4(\mathrm{l})$ bar. $\rho(\mathrm{CO})=2$ bar $)$. a) $\mathrm{A}$ : metal component $\left[\left(\mathrm{C}_{3} \mathrm{H}_{5}\right) \mathrm{PdI}\right]_{2}, \mathrm{~B}:\left[\mathrm{Pd}\left(\mathrm{CH}_{3} \mathrm{CN}_{4}\right]\left(\mathrm{BF}_{4}\right\rangle_{2}+\operatorname{ligand}\right.$ (cf. Scheme 2). b) selectivity for ethylvinylketone. based on the CO converted. c) catalyst solution prepared by reacting [ $\mathrm{Pd}(\mathrm{dppp}) \mathrm{Cl}_{2}$ ] (suspension of $\left(0.130 \mathrm{mmol}\right.$ in $20 \mathrm{ml} \mathrm{CH}_{2} \mathrm{Cl}_{2}$ ) with $\mathrm{Ag} \mathrm{F}_{4}$ (solution of $(0.26) \mathrm{mmol}$ in $0.5 \mathrm{~m}$ ] $\left.\mathrm{CH}_{3} \mathrm{CN}\right)$ and subsequent filtration.

thought to be lormed via the water-gas shift reaction from $\mathrm{CO}$ and trace impurities of water $[11,12]$.

The structure of the oligomeric products obtained in this study is aiso consistent with a hydride mechanism. Stoichiometric reactions of the catalyst precursors with ethylene and $\mathrm{CO}[16]$ support the mode of activation depicted in the selfexplanatory Scheme 3.

\section{Conclusion}

When working in methylene chloride as a solvent, the palladium catalyzed copolymerization ethylene and $\mathrm{CO}$ can be directed towards formation of low-molecular-weight cooligomers by applying high ethylene/CO ratios. Unsaturated ketones of the general structure $\mathrm{R}\left[\mathrm{C}(\mathrm{O}) \mathrm{CH}_{2} \mathrm{CH}_{2}\right]_{m,} \mathrm{H}$ ( $\mathrm{R} \equiv \mathrm{CH}_{2}=\mathrm{CH}-, \mathrm{CH}_{2}=\mathrm{CHCH}_{2} \mathrm{ClH}_{2}$ and $\mathrm{CH}_{3} \mathrm{CH}=$ $\mathrm{CHCH}_{2-}$ ) are obtained (i.e. $m=1$ : elhylvinylke. tone. 5- and 6-hepten-3-ones: $m=2$ : 1-octen-3.6dione. 8-and 9-decen-3.6-diones). Selectivities for ethylvinylketone of up to $43 \%$, based on the CO converted. were observed using $\mathrm{P}^{\prime \prime} \mathrm{Bu} \mathrm{u}_{3}$ as a ligand.

Cationic palladium ally! complexes with hemilabile bidentate ligands can be applied as singlecomponent catalyst precursors. It is assumed that phosphino-cster and phosphino-thiophene ligands behave like monodentate phosphines under catalytic conditions.

\section{Experimental}

All operations involving organometallic compounds and phosphine ligands were carried out under a dry argon atmosphere by standard Schlenk techniques. Methylene chloride was distilled from $\mathrm{CaH}_{2}$ under argon. $\left[\mathrm{Pd}\left(\mathrm{CH}_{3} \mathrm{CN}\right)_{4}\right]\left(\mathrm{BF}_{4}\right)_{2}$ was prepared according to [6]: $\left[\left(\mathrm{C}_{3} \mathrm{H}_{5}\right) \mathrm{PdI}\right]_{2}$ was obtained from $\left[\left(\mathrm{C}_{3} \mathrm{H}_{5}\right) \mathrm{PdCl}\right]_{2}$ [23] by halide exchange with $\mathrm{NaI}$ [24]. Phosphine ligands were obtained commercially or prepared by standard procedures. Cationic paliadium complexes with bidentate P,Oor P.S-ligands were prepared according to [16] and [17]. respectively. Ethylene (purity $>99.5 \%$ ) and carbon monoxide (purity $>99.99 \%$ ) were used as received. 1-Octen-3.6-dione was prepared by the procedure described in [25].

Gas chromatographic analyses were performed on a Siemens Sichromat with a $50 \mathrm{~m}$ Pona HP column. For GC-MS analyses a Varian 3700 gas chro. matograph combined with a Varian MAT $112 \mathrm{~S}$ mass specirometer was used. GC-IR were performed on a Hewlett-Packard 5890 II gas chromatograph equiped with a HP 5965 A IR-detector. NMR spectra were obtained on Varian VXR 3(4) and Unity 500 spectrometers. IR-spectra were recurded un a Nicolet 510 P FT-spectrometer. 


\section{Preparation of in silu catalyss:}

Procedurc A: To a solution of $0.05 \mathrm{mmmol}$ $\left[\left(\mathrm{C}_{3} \mathrm{H}_{a}\right) \mathrm{Pdl}\right]_{2}$ in $\mathrm{I}() \mathrm{ml}$ methylene chloricle a solution of one equivalent of monodentate phosphine ligand in $10 \mathrm{ml}$ methylenc chloride was added. After stirring for $30 \mathrm{~min}$. one equivalent of ethylacelate was added. and the yellow solution was (ransferred to a 5() $\mathrm{ml}$ round-bollom flask containing 1.01 equivalent of AgSbF ${ }_{n}$. Agl precipated inmediately. After stirring for $5 \mathrm{~min}$. the mixture was filtered over celitc. A clear yellow filtrate was ohtained.

Procedure B: 'io a suspension of ().l mimol $\left[\mathrm{Pd}\left(\mathrm{CH}_{3} \mathrm{CN}\right)_{4}\right]\left(\mathrm{BF}_{4}\right)_{2}$ in $10 \mathrm{ml}$ methylene chloride 1 solution of the appropriate amount of ligand in $10 \mathrm{ml}$ methylene chloride was added. Alter stirring for a few minutes. a clear yellow to orange solution was oblained.

\section{Couligomerization and copolymerizarion of eshvleme and carbon monoxide}

Calalylic experiments were carried out in $75 \mathrm{ml}$ V4A-steel auloclaves equiped with a magnelic stirrer bar. The calalyst solution was transferred to the autoclave under protective gas atmosphere via a syringe. Subsequently. the autoclave was purged and pressurized with ethylene. then $\mathrm{CO}$ was introduced and the autoclave was heated in an oil bath for the given reaction time. By weighing the autoclave. the amount of ethylene and $\mathrm{CO}$ was determined. After rapidly cooling to room temperature. unreacled gases were vented. CAUTION: vinylketones are highly toxic! 'The reaction mixture was iltered on a frit. the solid residuc was dried in a stream of argon and weighed. The filtrate was distilled at $75^{\circ} \mathrm{C}$ and ().1 mbar. The distillate. which contains the oligoketones with $m=1$ and 2 . was analyzed by $G C$ with $n$-heptane and n-dodecane as internal standards. The distillation residue was weighed. thus the amount of soluble cooligomers with $m \geq 3$ was delermined.

\section{Itentifications of enthlene-CO cooligamers and copeolymers}

For identification of the oligomeric products with $m=1.2$ and 3 a reaction mixlure was andlyzed by GC-MS and GC-IR. Also elhylvinylketone. a mixture of the isomeric 5- and 6-hepten3-ones. 1-octen-3.6-dione and a mixture of 8- and 9-decen-3.6-diones were separated by vacuum dis- tillation and identified by ' $\mathrm{H}$ and ${ }^{13} \mathrm{C}$ N.MR. Ethylvinylketonc and I-octen-3.6-dione were also idenlified hy GC analysis of a reaction mixture. 10 which a genuine sample of the compound had been added. The soluble product fraction with $m \geq 3$ was characterized by ' $H$ and ${ }^{1}{ }^{3} \mathrm{C}$ ' NMIR in $C D 1_{3}$ : the average chain length is $m=4107$. Spectroscopic data of the ahove compounds has been described in literature [19]. The complete data mentioned in this paragraph is given in [16].

The insoluble product fraclion was analyzed by IR $(\mathrm{KBr})$ and by ${ }^{1} \mathrm{H}$ and $\left.{ }^{13} \mathrm{C}^{-}{ }^{1} \mathrm{H}\right\}$ N.MIR in 1.1.1..3.3.3-hexalluoropropiln-2-ol containing 10) vol.-\% of $(n, 1)_{n}$. Except for the signal of the polymer backbone (s with $\delta=2.8$ ). 'll N.MR specira show ethyl end-groups ( $q$ with $\delta=2.5$ and 1 with $\delta=1.1$ ) and unresolved multiplets with $\delta=6.3$ and 6.(), assigned to vinyl end groups. In the ${ }^{1.3} \mathrm{C}$ N.MR spectra. except for the polymer backbone $(\delta=215.1$ and 37.6), small signals with $\delta=219.4$. 206.7. 137.1. 13.3.5, 34.3 and 8.4 are observed. which are also consistent with ethyl and vinyl end groups.

\section{Oligomeriautum of exhylene}

A solution of (0.05 mmol complex in $20 \mathrm{ml}$ methylene chloride was introduced into a steel autoclave (vide supra). The autoclave was purged with ethylene. pressurized to 30 bar. and was then heated in an oil bath for + hours. During the reaction the pressure was kept constant by continu. ously feeding ethylent. After rapidly cooling the autoclave to room temperature, the gas phase was vented via a cold trap $\left(-78^{\circ} \mathrm{C}\right)$. By weighing the autoclave before pressurizing and after venting and by weighing the cold trap, the amount of ethylene converted was calculated. The reaction mixiure was flash-distilled $(200)^{\circ} \mathrm{C}$ : ().1 mbar) from the calalyst. Selectivities for hexenes and higher oligomers were determined by GC with $n$-hepsanc as an internal standard.

\section{Ackmonledgements}

We are grateful to BP Chemicals for financial support. and we thank the members of the polyketone group of BP chemicals for valuable discussions. We also thank Wollgang Coertz. Ana Martinez-Velarde. Stefanie Vonderhank. Frank Faßbender. Beale Hofmann and Armin Kraus for their participation in this research as part of their undergraduale studies. 
(1) (2. Rocten. Ger. Pat. 849548 (1938).

[2] a) P. Pino. F. Piacinti. M. Bianchi. in I. Wender. P. Pino (ed:;): Orgaric Syntheses via Metal Carbonyls. 2. p. 215-231. Wiley Interscience. New Yurk (1977); b) H. M. Colguhoun, D.J. Thompson. M. V. Twigg, Carbonvition: Direct Svimbesis of Carbousl Compounds. Plenum l'ress, New York, Lundon (1991).

[3] a) K. Murata. A. Matsuda. Bull. Chem. Soc. Jpn. 54. $2(18)-2(1) 92(1981)$

b) V. N. Zudin. (i. N. Il'inich. V. A. Likholotorv. Y. I. Yermakosv. J. Chem. Soc. Chem. Commun. 1984, 545-546.

[4] W. Reppe, A. Magin. U. S. Pat. 2577208 (1951)

[5] a) Y. Iwashita. M. Sakuraba, Tetrahedron Letl. 1971, 2.4(1)9-2.+12:

b) A. Sen. J.S. Brumbaugh. M. Lin. J. Mol. Catil. 7.3, 297-32.i (1992):

c) M. van Ilatteren, Dissertation. RWTH Aachen (1991).

[6] T.-W. Lai. A. Sen, Organometallics 3, 866-870 (198.4).

[7] a) E. Drent (Shell), Eur. Pat. Appl. 121965 (1984):

b) E. Drent. J. A. M. van Broekhoven. M. J. Doyłe, J. Organomet. Chem. 417. 235-251 (1991).

[8] E. Drent. E. van Kragtwijk. D. H. L. Pello (Shell). Eur. Pal. Appl. 495547 (1992).

[9] C. Pisanos. G. Consiglio, A. Sironi, M. Moret. J. Chem. Soc. Chem. Commun. 1991, $421-423$.

[I0] a) J. D. McClure (Shell), Ger. Offen. DE 204606() (1971):

b) J. D. McClure. Ger. Offen. DE 2054307 (1971).

[11] E. Drent. Pure \& Appl. Chem. 62.661-669 (1 99()$)$.

[12] A. Sen. Acc. Chern. Res. 26, 303-310 (1993) and references cited therein.

(13) W. Keim. Angew. Chem., Int. Ed. Engl. 29. 235$244(199(1)$.
| 4 | G. J. I'. Britovsek. W. Keim. S. Mlecking. D. Sainz. T Wagner, J. Chem. Soc. Chells. Commun. 1993, $16.32-16.34$

[15] A. C. Bonnet. F. Dahan. A. Ecke. W. Keim. R. P Schuly. J. Tkatchenko. J. Chem. Soc., Chem. Cummun. 1994, 615-616.

[I6] S. Mecking. Disserlation, RIVTH Aachen (1994)

[17] a) H. Maas, Diploma thesis, IRWTH Aachen (1993); b) W. Keim. HI. Maas, unpublished results.

[18] a) 2. Jiang, G. M. Dahlen. K. Houseknechi. A. Sen. Macromolecules 25. 2999-3(x)l (1992):

b) A. X. Zhao. J. C. W. Chien. J. Polym. Sci. Part A. Polym. (hem. 30,2735-2747 (1992). cf. J. A. M. van Brockhoven. M. I. Doyle, E. Drent, ihid. 31. 2879 (199.3).

(I)] a) 5. and (3-he:pten-3-ones: K. P. Vora. C. F. Lochuw. R. (i. Miller. J. Orgintomet. Chem. 192, 257-264 (1980):

b) l-octen-3,6-dione and 1 -undecen-3,6-9-trione: $H$ Sictler. B, Jansen, Chem. Ber. I18, 4877-4883 (14)85):

c) 9-Llecerr-3.6-dione: B. Jansen. Dissertation. RIVTH Aachen (1984).

120| H. Stetter. H. Kuhimann. Organic Reactions 4f), $407-498$ (1991).

[21] A. Sen. T.-W. Lai. J. Am. Chem. Soc. 164. 35203522 (1982)

(22) E. Drent (Shell), Eur. Pat. Spec. 170311 (1985).

[23] Y. Tatsuno. T. Yoshida. Sciotsuka. Inorg. Synth. 19. 220-221 (1979).

[24] D. L. Tibbetis. T: L. Brown. J. Am. Chem. Soc. 91, $1108-1112$ (1 969).

[25] H. Sietter, A. Landscheidı, Chem. Ber. 112. 14101419 (1979). 